\title{
Receptor-mediated Endocytosis
}

Philip Stahl and Alan L. Schwartz

Department of Cell Biology and Physiology, Washington University School of Medicine, St. Louis, Missouri 63110;

Division of Pediatric Hematology/Oncology, Children's Hospital, Dana Farber Cancer Institute and Department of Pediatrics, Harvard Medical School, Boston, Massachusetts 02115

Receptor-mediated endocytosis is a process whereby extracellular macromolecules and particles gain entry to the intracellular environment (1-3). This process is common to virtually all eukaryotic cells except the mature erythrocyte. Cells use receptormediated endocytosis for a wide variety of functions. The most obvious of these activities is nutritional but others include host defense, transport, and processing. Some of these are listed in Table I. At least seven broad classes of ligand receptor systems involve receptor-mediated endocytosis (Table I). In general, macromolecular ligands bind to specific cell surface receptors which move to and cluster within specialized regions of the plasma membrane termed "coated pits" (4). These $0.1-\mu \mathrm{m}$ diam invaginations of the plasma membrane $(5,6)$ demonstrate a characteristic fuzzy cytoplasmic border when viewed in the transmission electron microscope (Fig. 1). This cytoplasmic coat is composed of a family of proteins with the major species having a molecular weight of $180,000 \mathrm{D}$, termed "clathrin" (7). In addition, these coat proteins generally include a pair of polypeptides of 33,000-35,000 D (referred to as clathrin light chains), a group of proteins of 100,000-110,000 D, a 50,000-D phosphoprotein, and the variable presence of a $56,000 \mathrm{D}$ protein (most probably tubulin) (8). In vitro and presumably in vivo, clathrin proteins self-assemble into a structure containing three heavy and three light chains. This structure has been termed a triskelion, denoting its three-legged appearance (9). When viewed as a rapid-freeze etched image under the scanning electron microscope, the coated pits and their progeny, the coated vesicles, appear as a cagelike structure composed of a polygonal lattice of hexagons and pentagons (10) (Fig. 2). The arrangement of the clathrin triskelions in cages is suggested by the shape and lengths of the arms, which appear to span two sides of the lattice. In all observed cage structures, three edges join at a vertex. Thus the assembly and packing of clathrin into the hexagons and pentagons may be analogous to the situation in spherical viruses $(8,11)$. In general, coated pits comprise $1-2 \%$ of the plasma membrane surface area of most cells (although certain types may contain much larger proportions).

Once receptors are bound with their appropriate ligands within the coated pits, the pits pinch off from the plasmalemma and become coated vesicles (50-150-nm diam) (12). This process of coated vesicle formation is simultaneous with the loss of ligand and receptor from the cell surface (i.e., internalization). Coated vesicles contain an abundance of both receptors and structural proteins. Receptors appear to randomly reside among the coated pits (13). Current data suggest that some coated pits

Received for publication 15 August 1985.

J. Clin. Invest.

(c) The American Society for Clinical Investigation, Inc.

0021-9738/86/03/0657/06 \$1.00

Volume 77, March 1986, 657-662 exist deep within the cytoplasm and are physically attached to the plasma membrane by a thin membraneous connection (14). This structure, however, appears to be impermeable to large as well as small molecules. Thus, for all practical purposes, these coated structures define a vesicular domain separate from either the extracellular environment or the cell cytoplasm.

Coated vesicles appear to be evanescent structures. Once the coated pits have severed their connections with the extracellular milieu, there is rapid disassembly of the clathrin coat and increased availability of disassembled clathrin within the cytoplasm (15). The disassembly and uncoating feature appears to be mediated by an ATP-dependent enzyme of 70,000 D, which results in a stoichiometric complex of this uncoating ATPase and triskelions (16). The resultant smooth-surfaced uncoated vesicles together with their contents of ligands and receptors are now delivered to the endosomal compartment (17). Several major questions regarding internalization of receptor ligand complexes remain unanswered: $(a)$ What information is present in the receptor molecule that causes it to cluster in the plane of the membrane over the coated pit? $(b)$ What is the signal for decoating to commence? $(c)$ Are there molecules present in the membranes of uncoated vesicles which mediate recognition and fusion events? $(d)$ Is clathrin reutilized?

The endosomal compartment is composed of a network of tubules and vesicles which may form a reticulum within the peripheral cytoplasm of the cell (18-20). This complex structure is the compartment in which many ligands dissociate from their receptors and in which many receptors sort from one another. This group of structures has been termed endocytotic vesicles, endosomes, receptosomes, and compartment of uncoupling receptor and ligand (CURL). ${ }^{1}$ This intracellular compartment is similar but not identical in various cell types. For example, in fibroblasts, individual units may exist, whereas in the highly polarized hepatocyte, there appears to be both a peripheral and a deeper (or Golgi-associated) CURL. Whether the peripheral and deep CURL are interconnected remains to be established. Both the endocytotic compartment $(21,22)$ as well as the coated vesicles which deliver the ligand/receptor contents are acidified by proton pumps that reside within the membranes of the respective compartment(s) (23). The acidic nature of the endosomal compartment, which was first demonstrated by Tycko and Maxfield (24), appears to be responsible for the dissociation of most ligands and receptors and thus plays a central role in directing various ligands and receptors to their appropriate destinations. The requirement for acidification explains the effects of weak bases which have been known for some time to block receptor-mediated endocytosis (25) and to protect cells against

1. Abbreviations used in this paper: CURL, compartment of uncoupling receptor and ligand; EGF, epidermal growth factor; PDGF, platelet-derived growth factor. 
Table I. Classes of Receptor Ligand Systems

\begin{tabular}{|c|c|c|c|c|}
\hline & Ligand & Receptor & Cell types & References \\
\hline \multirow[t]{4}{*}{ Cell nutrients } & LDL (cholesterol) & LDL-R & all & 70 \\
\hline & transferrin (iron) & transferrin- $\mathbf{R}$ & all & $71-72$ \\
\hline & vitellogenin & vitellogenin- $\mathbf{R}$ & egg & 73 \\
\hline & transcobalamin $\left(\mathbf{B}_{12}\right)$ & TC-II-R & all & 74 \\
\hline \multirow[t]{5}{*}{ Growth factors and hormones } & insulin & insulin- $\mathbf{R}$ & adipocyte & 75 \\
\hline & 政 & & hepatocyte & 76 \\
\hline & EGF & EGF-R & epithelial & $77-78$ \\
\hline & PDGF & PDGF-R & epithelial & $79-80$ \\
\hline & $\begin{array}{l}\text { luteinizing hormone/follicle-stimulating hormone/ } \\
\text { human chorionic gonadotropin }\end{array}$ & gonadotropin- $\mathbf{R}$ & gonadal & 81 \\
\hline Viruses & influenza & $?$ & & $82-83$ \\
\hline \multirow[t]{3}{*}{ Toxins } & diphtheria & $?$ & & 27,84 \\
\hline & pseudomonas exotoxin & $?$ & & 27 \\
\hline & ricin & $?$ & & 27 \\
\hline \multirow[t]{5}{*}{ Protein clearance systems } & mannosylated proteins & mannose- $R$ & macrophage & 85 \\
\hline & asialoglycoproteins & ASGP-R & hepatocyte & $86-87$ \\
\hline & $\alpha$-2-macroglobulin-protease & $\alpha-2 \mathrm{M}-\mathrm{R}$ & $\begin{array}{l}\text { fibroblast } \\
\text { macrophage }\end{array}$ & 88 \\
\hline & Fc & Fc-R & macrophage & 34 \\
\hline & modified lipoproteins & scavenger- $R$ & macrophage & 89 \\
\hline \multirow[t]{2}{*}{ Transcellular systems } & IgA & IgA-R & epithelial & 61 \\
\hline & IgG & IgG-R & gut epithelial & 62 \\
\hline \multirow[t]{4}{*}{ Protein processing } & antigen (lysozyme) & Ia & macrophage & 90 \\
\hline & lysosomal enzymes & M-6-P-R & fibroblast & $91-92$ \\
\hline & f-met-leu-phe & chemotactic peptide- $\mathbf{R}$ & granulocyte & 93 \\
\hline & parathyroid hormone & PTH-R & macrophage & $94-95$ \\
\hline
\end{tabular}

diphtheria toxin and certain viruses. Ligands, such as influenza virus, penetrate into the cell cytoplasm following $\mathrm{pH}$-mediated fusion of their coat proteins with the limiting membrane of the sorting compartment (26). Toxins, such as diphtheria toxin and ricin, also appear to gain access to the cytoplasmic compartment by penetrating the endosomal membrane (27). Ricin, a plant toxin consisting of two polypeptide chains connected by disulfide bonds, binds receptors through its $B$ chain while the $A$ chain traverses the membrane. Diphtheria toxin operates by a similar mechanism except that the endosomal $\mathrm{pH}$ gradient is required for toxin translocation. The proton pump responsible for acidification is present in endosomal membranes. The pump is electrogenic and operates most efficiently in the presence of a permeant anion (e.g., $\mathrm{Cl}^{-}$). There may be anion channels present in endosomal membranes. It is also likely that a carrier for $\mathrm{Fe}^{+3}$ is present in endosomal membranes because transferrin, which is rapidly internalized, releases its iron upon acidification. Apotransferrin remains receptor-bound and recycles with its receptor back to the cell surface $(28-30)$ while the released $\mathrm{Fe}^{+3}$ is incorporated into cytosolic proteins. A major question, apart from how the proton pump operates, is whether the pump is a permanent resident of endosomal membranes or whether it recycles to and from the cell surface. The evidence, although indirect, would favor the latter. A second question is whether the endosomal pump and lysosomal pump are one and the same or dif- ferent molecules. Recent evidence suggests that the two may be different (31).

The uptake of ligand into cells via a variety of receptor systems often proceeds linearly with time over extended periods, even in the absence of protein synthesis. It is now appreciated that the receptor molecules for most of these systems recycle back to the cell surface from the acidic intracellular compartments. This then allows a single receptor molecule to direct the cellular uptake of up to 300 ligand molecules per lifetime (3233). Many receptors (e.g., low density lipoprotein [LDL], transferrin, and asialoglycoprotein) are efficiently recycled, whereas others such as the insulin receptor or Fc receptor recycle much less efficiently (34). The recycling of the virus and toxin receptors is not defined at present. A complete cycle can occur in as little time as $8-10$ min $(32,33,35)$. Physiologically, this may have enormous consequences. For example, during development, a single avian oocyte may accumulate more than $1 \mathrm{~g}$ of protein per day (36).

Recently it has been shown that some internalized receptorligand complexes remain associated and return to the surface intact. These complexes are capable of dissociating but apparently never enter an acidic compartment (37). Recycling of ligand molecules such as this has been demonstrated for mannosylated proteins (38), asialoglycoproteins (39), and LDL (40). This process, also termed retroendocytosis or diacytosis, delivers unde- 


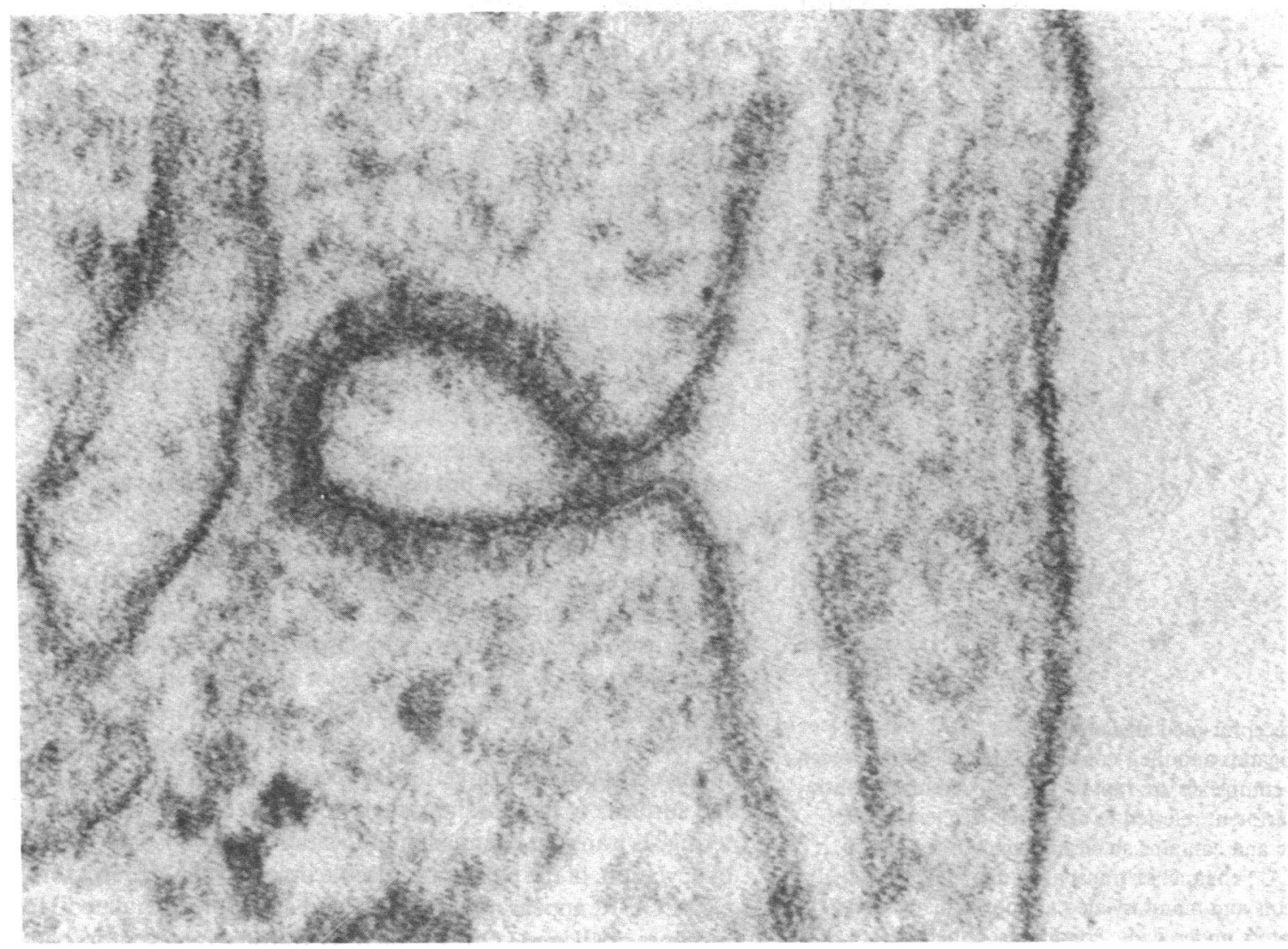

Figure 1. Transmission electron micrograph of hepatic parenchymal cell demonstrating coated pit. An endothelial cell lies to the right of the hepatic parenchymal cell. (Courtesy of Dr. H. J. Geuze).

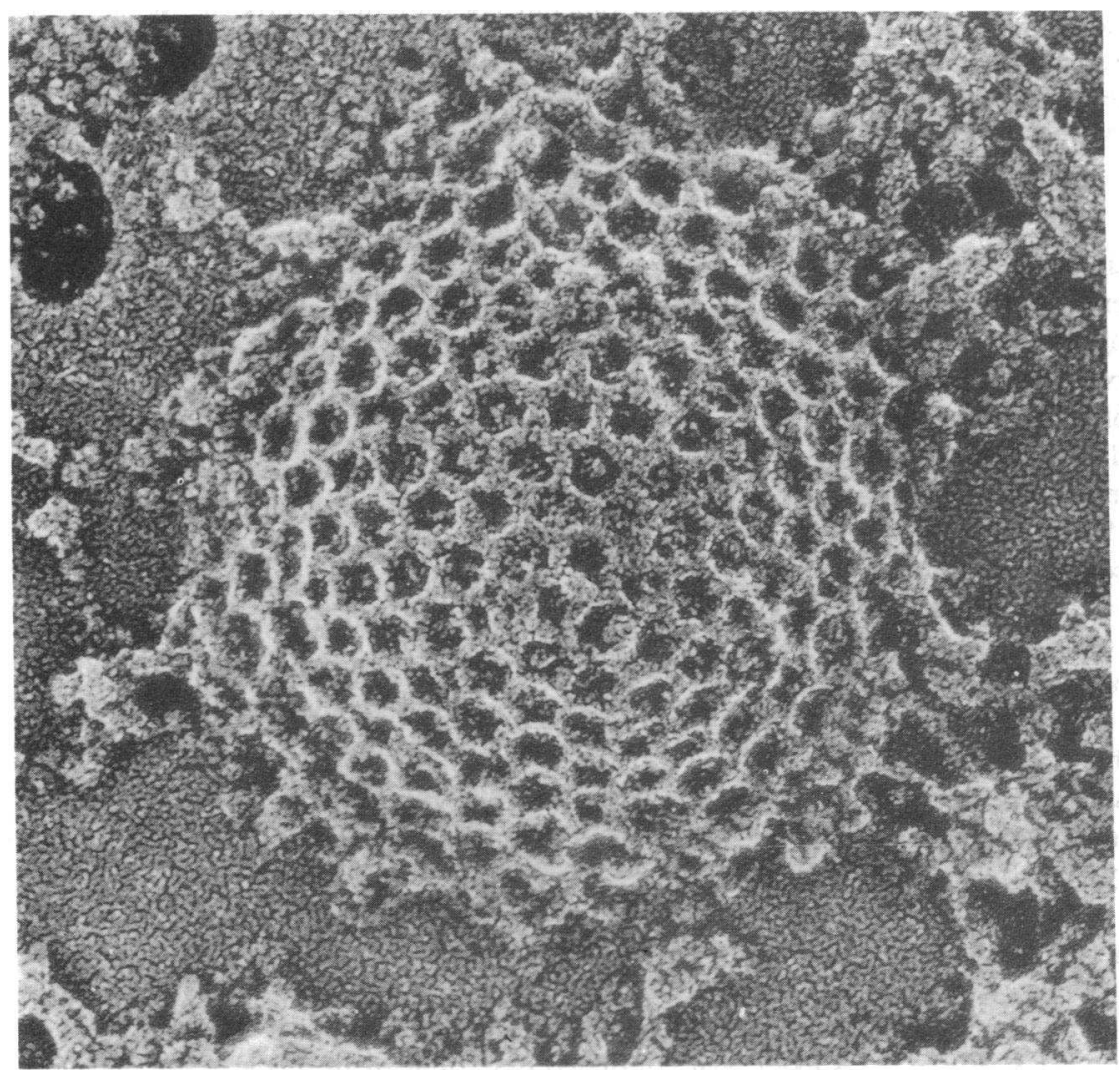

Figure 2. A freeze etch view of the inside of a fibroblast plasma membrane showing a forming coated vesicle. The characteristic basketlike structure is shown. (Reprinted from Heuser and Evans [10]). 


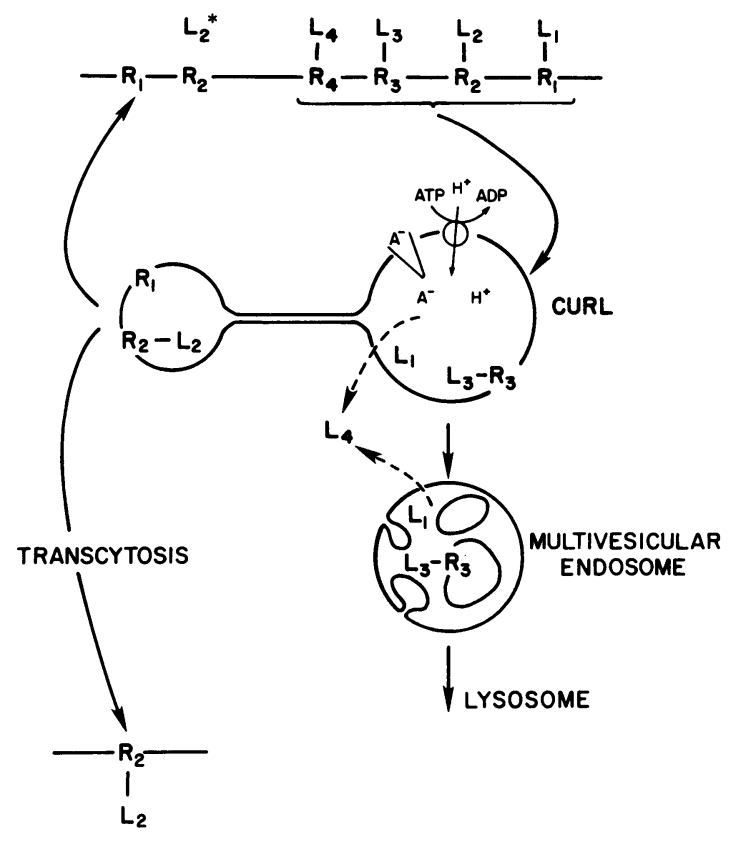

Figure 3. Model for receptor-mediated endocytosis. L1-L4 and R1R4 refer to different ligands and their corresponding cell surface receptors. Receptor ligand complexes are rapidly internalized into an intracellular sorting compartment referred to as CURL (see text). The compartment is acidic and contains an electrogenic proton pump along with an anion $\left(A^{-}\right)$channel or transporter. Some ligands $\left(L_{1}\right)$ (e.g., asialoglycoproteins and mannosylated glycoproteins) are separated from their receptors under acidic conditions. Others $\left(L_{2}\right)(e . g$., transferrin and $\operatorname{lgG}$ ) remain bound to their receptors under acidic conditions. Both $R_{1}$ and $R_{2}$ are segregated and rapidly recycled to the cell surface. In polarized cells, receptor ligand complexes $\left(R_{2}-L_{2}\right)$ may traverse the cell. Ligands, such as hormones $\left(\mathrm{L}_{3}\right)$ (e.g., insulin and EGF), may move with their receptors to multivesicular endosomes and then to secondary lysosomes where degradation occurs. Receptor degradation may be involved in hormone signalling. Still other ligands $\left(\mathrm{L}_{4}\right)$ (e.g., diphtheria toxin) may traverse the membrane and enter the cytoplasm under the acidic conditions of CURL.

graded ligand back to the cell surface. The physiologic function of this alternative pathway, if one exists, is not certain at present.

The signals which govern receptor recycling lie both with the ligand as well as within the receptor. Receptors will internalize and recycle in the absence of their ligand but often at a slower rate ("constitutive recycling") (41-43). Ligand binding to receptors may trigger one of many regulatory events. Binding of insulin (44), epidermal growth factor (EGF) (45), and plateletderived growth factor (PDGF) (46) to their respective receptors initiates both autophosphorylation of the receptor molecule (on its cytoplasmic tail) and internalization. Phosphorylation of transferrin receptor (47) also may signal receptor movement although the ligand, transferrin, does not appear to regulate this. The adrenergic receptor is phosphorylated and this modification correlates with loss from the cell surface (presumably intracellular sequestration) $(48,49)$. The phosphorylation state and regulation of many other recycling receptors are currently being investigated.

The structure of the receptor molecules may confer cellular signals for internalization and/or recycling. The primary amino acid sequence is now known for at least six receptors involved in receptor-mediated endocytosis (LDL receptor [50], EGF re- ceptor [51], asialoglycoprotein receptor [52, 53], insulin receptor $[54,55]$, IgA receptor [56], and transferrin receptor $[57,58]$ ). There does not appear to be any substantial similarity between any two receptors in terms of orientation in the membrane, primary sequence, or modification. Nonetheless, study of human genetic mutants of the LDL receptor has begun to shed considerable light on the role of receptor structure and function. For example, it has been found that the LDL receptor, when synthesized without its cytoplasmic tail or transmembrane portion, is secreted and thus is not capable of internalization (59). Similarly, deletion mutations or single amino acid mutations in the cytoplasmic tail of the receptor also result in absence of LDL receptor internalization $(60)$.

Additional sorting cues appear to be involved in the receptormediated endocytosis, uptake, and transcellular passage of IgA (61) or IgG (62) in epithelial cells including the neonatal gut. IgA, when bound to its receptor at the blood front (basolateral cell surface), is endocytosed together with its receptor and targetted to the apical cell surface, where the IgA is secreted covalently bound to the extracytoplasmic portion of its receptor (i.e., secretory component). A major unanswered question is how receptors are clustered and sorted within the endocytotic CURL compartment for transport to the cell surface. Is clathrin involved and is this targetting process similar to clustering on the surface? Is membrane potential involved in receptor clustering? Is transient chemical modification, e.g., phosphorylation or acylation, of the receptor molecule involved? Some receptors, e.g., EGF-R, appear not to recycle and are "down-regulated" in response to ligand. Others, such as transferrin receptors, are down-regulated when cells do not require ligand. In the case of transferrin, down-regulation occurs when cells have sufficient iron stores or when the need for iron is reduced, e.g., following maturation of a reticulocyte into an erythrocyte. What is the fate of receptors which are down-regulated? Experiments with ligand bound to gold colloid or ferritin indicate that such endocytosed markers pass through CURL and then reside temporarily in multivesicular endosomes. Receptors that are targetted to lysosomes may be selectively invaginated into the multivesicular endosome which ultimately fuses with primary or secondary lysosomes. An interesting variant of this kind of mechanism has been found with reticulocytes bearing transferrin receptors. When reticulocytes mature into erythrocytes, transferrin receptors are "down-regulated". With each passage through the normal transferrin receptor cycle, a certain number of receptors pass into multivesicular endosomes. Normally, these structures would be expected to fuse with secondary lysosomes; however, in the reticulocyte, for reasons yet unclear, multivesicular bodies which contain transferrin receptors fuse with the plasma membrane (63-64). The released blebs which can be recovered contain sufficient transferrin receptors to account for down-regulation. How transferrin receptors are selectively culled away from the normal recycling pathway is unknown.

Thus, following internalization, receptors appear to follow multiple pathways in cells (Fig. 3). The pathway may vary depending upon the structure of the receptor and the cell type involved. Understanding these pathways and elucidation of their mechanisms has already shed new light on the structural bases for inherited disorders $(60,65)$, the phenomenon of drug desensitization (66), and hormone-mediated down-regulation (67). It is likely that continued development in this area will have an 
impact in therapeutics by providing a basis for site-directed targetting of immunotoxins (68) and drugs (69).

\section{Acknowledgments}

The authors were supported in part by National Institutes of Health grant CA 12858 and GM 32477 and the National Foundation. Dr. Schwartz is an Established Investigator of the American Heart Association.

\section{References}

1. Goldstein, J. L., R. G. W. Anderson, and M. S. Brown. 1979. Nature (Lond.). 279:679-685.

2. Goldstein, J., M. Brown, R. G. W. Anderson, D. W. Russell, and W. Schneider. 1985. Annu. Rev. Cell Biol. 1:1-40.

3. Wileman, T., C. Harding, and P. Stahl. 1985. Biochem. J. 232: $1-14$.

4. Anderson, R. G. W., M. S. Brown, and J. L. Goldstein. 1977. Cell. 10:351-364.

5. Anderson, R. G. W., J. L. Goldstein, and M. S. Brown. 1976. Proc. Natl. Acad. Sci. USA. 73:2434-2438.

6. Anderson, R. G. W., M. S. Brown, and J. L. Goldstein. 1981. J. Cell Biol. 88:441-452.

7. Pearse, B. M. F. 1976. Proc. Natl. Acad. Sci. USA. 73:1255-1259.

8. Harrison, S., and T. Kirchhausen. 1983. Cell. 33:650-652.

9. Ungewickell, E., and D. Branton. 1981. Nature (Lond.). 239:420422.

10. Heuser, J., and L. Evans. 1980. J. Cell Biol. 84:560-583.

11. Crowther, R., and B. M. F. Pearse. 1981. J. Cell Biol. 91:790797.

12. Fine, R., and C. Ocklesford. 1984. Int. Rev. Cytol. 91:143.

13. Geuze, H. J., J. W. Slot, G. J. A. M. Strous, J. Peppard, K. von Figura, A. Hasilik, and A. L. Schwartz. 1984. Cell. 37:195-204.

14. Willingham, M. C., and I. Pastan. 1983. Proc. Natl. Acad. Sci. USA. 80:5617-5621. 527.

15. Goud, B., C. Huet, and D. Louvard. 1985. J. Cell Biol. 100:521-

16. Schlossman, D. M., S. Schmid, W. Braell, and J. E. Rothman. 1984. J. Cell Biol. 99:723-733.

17. Helenius, A., I. Mellman, D. Wall, and A. Hubbard. 1983. Trends Biochem. Sci. 8:245-250.

18. Geuze, H. J., J. W. Slot, G. J. A. M. Strous, H. Lodish, and A. L. Schwartz. 1983. Cell. 32:277-287.

19. Hopkins, C. R. 1983. Cell. 35:321-330.

20. Harding, C., A. L. Levy, and P. Stahl. 1985. Eur. J. Cell Biol. 36:230-238.

21. Anderson, R. G. W., J. R. Galck, J. L. Goldstein, and M. S. Brown. 1984. Proc. Natl. Acad. Sci. USA. 81:4838-4842.

22. Schwartz, A. L., G. J. A. M. Strous, J. W. Slot, and H. J. Geuze. 1985. EMBO (Eur. Mol. Biol. Organ.) J. 4:899-904.

23. Ives, H. D., and F. C. Rector. 1984. J. Clin. Invest. 73:285-290.

24. Tycko, B., and F. R. Maxfield. 1982. Cell. 28:643-661.

25. Tietze, C., P. Schlesinger, and P. Stahl. 1980. Biochem. Biophys.

Res. Commun. 93:18-23.

26. Marsh, M. 1984. Biochem. J. 218:110-118.

27. Olsnes, S., and A. Phil. 1982. Pharmacol. Ther. 15:355-381.

28. Klausner, R. D., G. Ashwell, J. van Renswoude, J. Harford, and

K. R. Bridges. 1983. Proc. Natl. Acad. Sci. USA. 80:2263-2266.

29. Dautry-Varsat, A., A. Ciechanover, and M. F. Lodish. 1983.

Proc. Natl. Acad. Sci. USA. 80:2258-2262.

30. Harding, C., and P. Stahl. 1983. Biochem. Biophys. Res. Commun. 113:650-658.

31. Merion, M., and W. S. Sly. 1983. J. Cell Biol. 96:644-650.

32. Brown, M. S., R. G. W. Anderson, and J. L. Goldstein. 1983. Cell. 32:663-667.
33. Wileman, T., R. Boshans, P. Schlesinger, and P. Stahl. 1984. Biochem. J. 220:665-675.

34. Mellman, I. S., and H. Plutner. 1984. J. Cell Biol. 98:1170-1177. 35. Schwartz, A. L., S. E. Fridovich, and H. F. Lodish. 1982. J. Biol. Chem. 257:4230-4237.

36. Cutting, J. A., and T. F. Roth. 1973. Biochim. Biophys. Acta. 298:951-955.

37. Wileman, T., R. Boshans, and P. Stahl. 1985. J. Biol. Chem. 260:7387-7393.

38. Tietze, C., P. Schlesinger, and P. Stahl. 1982. J. Cell Biol. 92: 417-424.

39. Simmons, C. F., and A. L. Schwartz. 1984. Mol. Pharmacol. 26: 509-519.

40. Goldspan, P., and R. W. St. Clair. 1984. J. Biol. Chem. 259: 1703-1710.

41. Basu, S. K., J. L. Goldstein, R. G. W. Anderson, and M. S. Brown. 1981. Cell. 24:493-502.

42. Schwartz, A. L., A. Bolognesi, and S. E. Fridovich. 1984. J. Cell Biol. 98:732-738.

43. Watts, C. 1985. J. Cell Biol. 100:633-637.

44. Kasuga, M., F. A. Karlsson, and C. R. Kahn. 1982. Science (Wash. DC). 215:185-187.

45. Carpenter, G., L. King, and S. Cohen. 1979. J. Biol. Chem. 254: 4884-4891.

46. Ek, B., B. Westermark, A. Wasteson, and C. H. Heldin. 1982. Nature (Lond.). 295:419-421.

47. Schneider, C., R. Sutherland, R. Newman, and M. Greaves. 1982. J. Biol. Chem. 257:8516-8522.

48. Stadel, J. M., P. Nambi, R. G. L. Shorr, D. F. Sawyer, M. G. Caron, and R. J. Lefkowitz. 1983. Proc. Natl. Acad. Sci. USA. 80:31733177.

49. Sibley, D. R., R. H. Strasser, M. G. Caron, and R. J. Lefkowitz. 1985. J. Biol. Chem. 260:3833-3886.

50. Russell, D. W., W. J. Schneider, T. Yamomoto, K. L. Luskey, M. S. Brown, and J. L. Goldstein. 1984. Cell. 37:577-585.

51. Ullrich, A., L. Coussens, J. S. Hayflick, T. J. Dull, A. Gray, A. W. Tam, J. Lee, L. Y. Yarden, T. A. Liberman, J. Schlessinger, J. Downward, E. L. V. Mayes, N. Whittle, M. D. Waterfield, and P. H. Seeburg. 1984. Nature (Lond.). 309:418-425.

52. Drickamer, K., J. F. Maman, G. Binns, and J. O. Leung. 1984. J. Biol. Chem. 259:770-778.

53. Spiess, M., A. L. Schwartz, and H. F. Lodish. 1985. J. Biol. Chem. 260:1979-1982.

54. Ullrich, A., J. A. Bell, E. Y. Chen, R. Herrera, L. M. Petruzzelli, T. J. Dull, A. Gray, L. Coussens, Y. C. Liao, M. Tubokawa, A. Mason, P. H. Seeburg, C. Grunfeld, O. M. Rosen, and J. Ramachandran. 1985. Nature (Lond.). 313:756-761.

55. Ebina, Y., L. Ellis, K. Jarnagin, M. Edery, L. Graf, E. Clausner, J. H. Ou, F. Masiarz, Y. W. Kan, I. D. Goldfine, R. A. Rothe, and W. J. Rutter. 1985. Cell. 40:747-758.

56. Mostov, K. E., M. Friedlander, and G. Blobel. 1984. Nature (Lond.). 308:37-43.

57. Schneider, C., M. J. Owen, D. Banville, and J. G. Williams. 1984. Nature (Lond.). 311:675-678.

58. McClelland, A., L. C. Kuhn, and F. H. Ruddle. 1984. Cell. 39: 267-274.

59. Lehrman, M. A., W. J. Schneider, T. C. Sudhof, M. S. Brown, J. L. Goldstein, and D. W. Russell. 1985. Science (Wash. DC). 227:140146.

60. Lehrman, M. A., J. L. Goldstein, M. S. Brown, D. W. Russell, and W. J. Schneider. 1985. Cell. 41:735-743.

61. Kuhn, L. C., and J. P. Kraenbuhl. 1982. Trends Biochem. Sci. 7:299-302.

62. Abrahamson, D. R., and R. Rodewald. 1981. J. Cell Biol. 91: 270-280. 
63. Harding, C., J. Heuser, and P. Stahl. 1983. J. Cell Biol. 97:329_ 339.

64. Pan, B. T., and R. M. Johnstone. 1983. Cell. 33:967-977.

65. Sudhof, T. C., J. L. Goldstein, M. S. Brown, and D. W. Russell. 1985. Science (Wash. DC). 228:815-822.

66. Lefkowitz, R. J., M. G. Caron, and G. L. Stiles. 1984. N. Engl. J. Med. 310:1570-1579.

67. Ronnett, G. V., V. P. Knutson, and M. D. Lane. 1982. J. Biol. Chem. 257:4285-4291.

68. Vitetta, E. S., and J. W. Uhr. 1985. Cell. 41:653-654.

69. Shepherd, V. L., P. Stahl, P. Bernd, and M. Rabinovitch. 1983. J. Exp. Med. 157:1471-1482.

70. Goldstein, J. L., and M. S. Brown. 1982. Clin. Res. 30:417-426.

71. Klausner, R. D., J. van Renswoude, G. Ashwell, C. Kempf, A. Schechter, A. Dean, and K. R. Bridges. 1983. J. Biol. Chem. 258:47154724.

72. Ward, J. H., I. Jordan, J. P. Kushner, and J. Kaplan. 1984. J. Biol. Chem. 259:13235-13240.

73. Woods, J. W., and T. F. Roth. 1984. Biochemistry 23:57745780.

74. Sennett, C., L. E. Rosenberg, and I. S. Mellman. 1981. Ann. Rev. Biochem. 50:1053-1086.

75. Marshall, S. 1985. J. Biol. Chem. 250:4133-4144.

76. Kahn, C. R. 1983. Clin. Res. 31:326-335.

77. Carpenter, G., and S. Cohen. 1976. J. Cell Biol. 76:159-171.

78. Carpenter, G. 1984. Cell. 37:357-358.

79. Helden, C. H., A. Wasteson, and B. Westermark. 1982. J. Biol. Chem. 257:4126-4221.
80. Deuel, T. F., and J. S. Huang. 1984. J. Clin. Invest. 74:669-676. 81. Ascoli, M., and D. Puett. 1978. J. Biol. Chem. 253:7832-7838. 82. White, J., M. Kielian, and A. Helenius. 1983. Q. Rev. Biophys. 16:151-195.

83. Marsh, M. 1984. Biochem. J. 218:110.

84. Dorland, R. B., J. L. Middlebrook, and S. H. Leppla. 1979. J. Biol. Chem. 254:11337-11342.

85. Stahl, P. D., J. S. Rodman, J. Miller, and P. H. Schlesinger. 1978. Proc. Natl. Acad. Sci. USA. 75:1399-1403.

86. Ashwell, G., and J. Harford. 1982. Annu. Rev. Biochem. 51:531554.

87. Schwartz, A. L. 1984. C.R.C. Crit. Rev. Biochem. 16:107-233.

88. Kaplan, J., and M. L. Nielsen. 1979. J. Biol. Chem. 254:73237328.

89. Goldstein, J. L., Y. K. Ho, S. K. Basu, and M. S. Brown. 1979. Proc. Natl. Acad. Sci. USA. 76:333-337.

90. Allen, P. M., and E. R. Unanue. 1984. J. Immunol. 132:10771079.

91. Sly, W., and H. D. Fisher. 1982. J. Cell Biochem. 18:67-85.

92. Hoflack, B., and S. Kornfeld. 1985. Proc. Natl. Acad. Sci. USA. 82:4428-4432.

93. Zigmond, S. H., S. J. Sullivan, and D. A. Lauffenberger. 1982. J. Cell Biol. 92:34-43.

94. Hruska, K., A. Korkor, K. Martin, and E. Slatapolsky. 1981. J. Clin. Invest. 60:885-892.

95. Zull, J. E., and J. Chuang. 1985. J. Biol. Chem. 260:1608-1613. 